\title{
Clinical Legal Education in Australia: A Historical Perspective
}

Jeff Giddings*

\section{Introduction}

The evening edition of the Melbourne Herald for Saturday, January 7, 1933 contains what is probably the first Australian reference to the clinical teaching of law students. ${ }^{1}$ Frank Russell, a lawyer, noted that, unlike medical clinics which provided 'the finest medical attention to the suffering poor', legal clinics were not well known in Australia. Russell noted that legal clinics were a familiar phenomenon in the U.S.A. and also existed in some countries of Europe and had been used in England. Russell outlined the operations of the Legal Clinic at the University of Southern California. Students interviewed indigent clients and then in appropriate cases provided ongoing assistance. Their work was supervised by experienced lawyers and the Dean of the Faculty of Law would attend from time to time 'to decide knotty cases, not of law, but of the propriety of the Clinic acting for applicants'.2

Russell's description is of a real client clinic with a strong community service focus, a clinic committed to the delivery of legal services to the disadvantaged. Australian clinical legal education programs (CLE) have tended to make use of this model since the establishment of the clinical program at Monash University in 1975. While the live-client model has been very influential, the history of Australian CLE is quite eclectic, with the stories and experiences varying significantly from state to state, law school to law school. The establishment of some programs was heavily student-driven while others saw a 'top down' approach taken, with academics developing programs which have then been enthusiastically accepted by students.

The article focuses on real client clinical work with participating students being supervised by lawyer academics while also referring to other models. This model has enabled clinics to retain a strong commitment to community service whilst also facilitating close work with small groups of students.

* Associate Professor, Law School, Griffith University

Thanks to the anonymous reviewer and the editors for their insightful comments on an earlier version of this article.
1 F. Russell, 'How to Educate Young Lawyers: Legal Clinics in the U.S.A.' Herald, Saturday Evening, January 7, 1933.

2 Id 
This has been important to the growing acceptance and popularity of CLE with students, law schools, universities and the legal profession. Use of the real-client model also suggests an aversion to the value-free approach to legal education exemplified by the Socratic appellate case method.

The first part of the article addresses the development of Australia's earliest clinical programs, those at Monash University, La Trobe University and the University of New South Wales. The second part provides an overview of increased Australian interest in CLE during the 1990s while the third part identifies some themes important in the history of Australian CLE.

\section{Early days for Australian Clinical Legal Education}

While the first formal clinical legal education program in Australia was established in 1975 at Monash University, several legal referral services involving students had earlier been established. In June 1970, Melbourne University law students opened a free legal referral service at the Church of All Nations in Carlton. Initially, 5 students participated in the service. ${ }^{3}$ In 1971, a telephone referral service run by Monash University law student volunteers with support from Law School academics commenced operation at the premises of the Melbourne Citizens Advice Bureau. ${ }^{4}$ Legal academics involved in these services, in particular Ronald Sackville at Melbourne and Peter Hanks at Monash, were also heavily involved in the rapid development of Australian legal aid policy around this time. ${ }^{5}$

In 1972, the Law Society at the Australian National University established a Legal Referral Service. The service ceased operations the following year, 'as a result of the establishment of "official" legal aid offices which led to the loss of a sense of purpose among students and through a lack of leadership of the participants. Another difficulty which faced the service was a degree of reserve concerning its function among the Canberra legal profession.' 6

\section{Monash}

Students played a key role in the establishment of the Monash clinical program in 1975. Simon Smith traces the origins of the program to the establishment in 1971 of the Monash Student Legal Referral Service, noted above. 'Working on roster, third, fourth and final year students would take telephone calls seeking legal assistance. As soon as the problem was identified a member of the Monash academic staff would be telephoned for the legal advice and referral which was then telephoned back to the original caller. ${ }^{7}$ The Referral Service was not part of the Monash curriculum and was not faculty-approved. ${ }^{8}$ Students were not formally prepared for their role nor was there any regulation of the academic advisors. ${ }^{9}$

3 J. Chesterman, Poverty Law and Social Change: The Story of the Fitzroy Legal Service, 1996, Melbourne University Press, 4 \&ु 26.

4 S. Smith, 'Clinical Legal Education: The Case of Springuale Legal Service' in Neal, D., (ed) On Tap, Not on Top: Legal Centres in Australia 1972-1982, 49

5 In his role as Commissioner for Law and Poverty to the Commission of Inquiry into Poverty 1972, Sackville wrote several influential reports, Legal Aid in Australia (1972), Legal Needs of the Poor (1975) and Law and Poverty in Australia (1976). Hanks published several reports for Commonwealth agencies, including
Relationship Between Legal Aid Agencies and Social Agencies (1983) and Social Indicators and the Delivery of Legal Services (1987).

6 J. Goldring \& R. Hamilton, A Course of "Clinical Legal Education" as part of the Law Degree Course at A.N.U. Discussion Paper, 14/4/78, 2.

7 S. Smith, Above, note 4, 49

8 G. Nash, 'Clinical Education in Australia' Council on Legal Education for Professional Responsibility, Vol. XII, No. 1, (1979) 6

9 Smith, above, note 4, 49 
Early in 1972, the referral service began running afternoon sessions at the Springvale Community Aid and Advice Bureau. This involved students in face-to-face interviews with clients with support from Bureau staff. Smith notes that student frustration with the limited nature of referral work and the example provided by the establishment in December 1972 of the Fitzroy Legal Service, contributed to Springvale Legal Service being established in February $1973 .{ }^{10}$ Law students were the main contributors to what was, quite understandably, a very busy and fairly disorganised service. Two of the students most heavily involved in the development of Springvale Legal Service, Neil Rees and Simon Smith, went on to play critical roles in the development of Australian CLE. Smith spent more than 10 years as Coordinator of Springvale Legal Service. Rees was the academic responsible for developing and implementing the UNSW clinical program in the early 1980s and later became Foundation Dean of the University of Newcastle Law School.

Monash academics, including Peter Hanks and Professor Gerry Nash, became involved in Springvale Legal Service and this prompted law school interest in the prospect of a clinical program. During 1973 and 1974, this prospect was discussed in forums including the Faculty Board. A Committee on Clinical Legal Education, chaired by Hanks, met after Faculty Board gave in principle approval to the establishment of a clinical program. ${ }^{11}$ Nash developed a subject proposal which was approved by the Faculty Board early in $1974 .{ }^{12}$ Nash did so after lengthy consultation with Professor Arthur Berney who was visiting Monash from Boston College Law School.

The elective subject 'Professional Practice' was offered on a pilot basis in second semester, 1975. The subject was based at Springvale Legal Service with 15 students being supervised by Professor Nash with assistance provided by three practitioners as part-time 'tutors'. The three practitioners were all active volunteers at the service and they each attended one evening per week to provide direct supervision of student work. Nash's supervisory role was of a more general nature. Nash had agreed to run the subject in an effort to overcome objections related to the cost of the program. This supervision represented half of Nash's teaching commitment for the semester. ${ }^{13}$

The first offering was obviously quite chaotic. According to Nash, he and Harry Reicher 'were just flat-out.' Professional Practice was then run over the summer of 1975/76. 'We had to run it over summer. We couldn't tell the clients to come back in 3 months time.' The summer subject offering was a first both for Monash University and for Australian law schools. ${ }^{14}$

Two further Monash clinic sites were subsequently developed; the Doveton Legal Service, which opened in mid-1977 and Monash-Oakleigh Legal Service, which opened in 1978. The possibility of establishing a clinic at the proposed Springvale office of the Australian Legal Aid Office, discussed in 1975 , had to be shelved when that office did not open. ${ }^{15}$

$10 \mathrm{Id}$

11 P. Hanks, 'Clinical Legal Education', Paper to members of the Committee on Clinical Legal Education, 3 May, 1974.

12 Nash, above, note 8, 6

13 Ibid, 8

14 Gerry Nash, personal interview, 1/12/97
15 It had been anticipated that a large number of branch offices of the ALAO would be opened during 1975 but this did not eventuate due to resistance from the legal profession and the change of Commonwealth government in December, 1975. For an account of this curtailment of the ALAO, see Tomsen, S., 'Professionalism and State Engagement: Lawyers and Legal Aid Policy in Australia in the 1970's and 1980's' (1992) 28 Australian and New Zealand Journal of Sociology 307 
Each of the clinics relied heavily on part-time tutors. One of the supervisors at Doveton was a local solicitor, Michael Duffy, who subsequently was Federal Attorney-General in the Hawke Labor Government. ${ }^{16}$ Nash hoped that over time more academics would become involved in the clinic and would be better teachers because of this involvement. However, this did not happen to the extent Nash hoped, with the clinics remaining relatively self-contained. ${ }^{17}$

The 3 Monash clinic sites differed in a number of significant aspects. Nash stated that it was 'interesting that the official philosophy (so far as the university is concerned and so far as I am concerned) behind the University operation of these three legal services is identical but the nature of the operation tends to differ.'18 While the 'great majority' of Springvale Legal Service clients were of non-English speaking origin, the corresponding figure for Doveton was $25 \% .{ }^{19}$ While arrangements were made at Doveton to limit to 20 the number of clients seen during any one session, the 'Springvale operation has always been premised on the assumption that all-comers should be served.'20

Nash also notes that the emphasis at Springvale was on 'informality and assistance to the client. Because of the ethos of the establishment, the way in which it originally began, and the personality of those who work there, the educational element is perhaps subservient to the legal aid element. ${ }^{21}$ The person who was central to the development of the particular Springvale Legal Service focus was Simon Smith. Smith was employed as an administrative assistant by Nash, by then the Law School Dean, in January 1978 although Smith's work was focussed on the coordination of the Springvale Legal Service legal practice and supervising students. The fact that Smith was employed as an administrative assistant rather than as an academic highlights that, although clinical legal education was further advanced at Monash than at any other Australian university, its legitimacy had not yet been accepted. Smith's position was not converted to a lectureship until 1982, 7 years after establishment of the clinical program.

The importance of Simon Smith's coordination role was increased because of the program's heavy reliance on part-time teachers. 11 part-time tutors were involved in student supervision at the Monash clinic sites during the three semesters completed in the 1979-80 financial year. ${ }^{22}$ Smith later referred to a stage where 8 different people were involved in supervision and teaching at Springvale Legal Service alone and the difficulties this caused for students in terms of access to tutors for follow-up supervision. Smith described this situation as unworkable. ${ }^{23}$ Further difficulties arose due to different styles of supervision. Guy Powles, then coordinator of the Monash clinical program, expressed concern that the clinical program not be built up through the employment of part time staff on an ad hoc basis:

'Above all else, the course requires continuity of supervision. What is needed is the part-time commitment of a full-time lecturer with good all round practical experience. $^{24}$

16 Nash, interview, 1/12/97

17 Nash, interview, 1/12/97

18 Nash, above, note 8, 15

19 Ibid, 13

20 Ibid, 14. It was not until November 1987 that a limit of 15 client interviews per session was introduced. See K. Greenwood, It Seemed Like a Good Idea at the Time,
1994, Springvale Legal Service, 127.

21 Ibid, 12

22 Attachment to Memorandum from Guy Powles to Professor Nash Re: Professional Practice tutors dated 4 October 1979.

23 Smith, above, note 4, 51

24 Id. 
At Monash, there was also a 'Godfather Scheme' whereby students were given the opportunity to shadow experienced practitioners. In 1980, there were 69 students placed, including the present Victorian Deputy Premier, John Thwaites and ABC Radio presenter Jon Faine. The program appears to have suffered from the inconsistencies in student learning which bedevil these external part-time programs.

The Monash clinical program has benefited greatly from continuity of staff in several key positions. Sue Campbell has coordinated the Monash program since the mid-1980s and both Simon Smith and Adrian Evans spent in excess of 10 years as Coordinator of Springvale Legal Service. Ross Hyams, currently Director of what is now known as the Springvale-Monash Legal Service, has also worked in the clinical program for more than 10 years, principally as Coordinator of Monash-Oakleigh Legal Service. During the 1990s, Monash developed specialist clinics as well as a model for involving clinic students in community development work, significant initiatives in the development of Australian CLE.

\section{La Trobe}

The La Trobe University clinical program can be traced to the 1974 establishment of the La Trobe Legal Service by staff from the Legal Studies Department. ${ }^{25}$ There was strong student demand both for the provision of legal services to the student population and for involvement in the delivery of those services. In 1976, the La Trobe Legal Service employed a lawyer with Students' Representative Council funds and by 1977 'it was clear that the time was ripe to begin training "para-legal" personnel for work in the service. ${ }^{26}$ This was done through a clinical course established by Adrian Evans, then a solicitor at the La Trobe SRC Legal Service, called Clinical Legal Education. Twelve students were placed with the SRC Legal Service as well as participating in seminars on interviewing skills and various substantive legal areas. The Legal Studies Department made a payment to the Legal Service for having the students on placement. ${ }^{27}$

In 1978, the Legal Studies Department also employed a lecturer in Legal Aid with responsibility for establishing the West Heidelberg Community Legal Service (WHCLS) at the local West Heidelberg Community Centre ${ }^{28}$ which became the second placement site for the La Trobe Legal Studies students. Phil Molan was the first person appointed to that position, which he held until 1981. ${ }^{29}$ A course titled Law and Social Justice developed out of the student work at WHCLS and students from the course continued to be placed at WHCLS until $1987 .^{30}$

The decision to provide a clinical program for legal studies students was based on the view that the agents for change of the legal system would come from outside the legal profession and that paralegals had a key role to play in improving the workings of the legal system. ${ }^{31} \mathrm{~A}$ focus of the program was the training of students to work as para-legal volunteers at the La Trobe Legal Service with such work continuing after the students' completion of the clinical program.

25 A. Evans, 'Para-legal Training at La Trobe University' (1978) 3 (2) Legal Service Bulletin 65.

26 Id.

27 M. A. Noone, 'Draft History of Clinical Legal Education in Legal Studies Department' (undated).

28 D. Neal, 'The New Lawyer Bloke' (1978) 3 (4) Legal Service Bulletin 148.
29 Phil Molan discussed his work in community legal centres, including the development of the West Heidelberg Community Legal Service in an interview with David Neal, 'Interviews: Some Founding Mothers and Fathers' in Neal, D., (ed) On Tap, Not on Top: Legal Centres in Australia 1972-1982, 60-64.

30 Noone, above, note 27.

31 A. Evans, interview, 17 October 1997. 
In 1986, Adrian Evans and Mary Anne Noone (who in 1985 had replaced Kevin Bell in the lecturer position originally held by Phil Molan) reviewed the Clinical Legal Education course with a view to involving both the La Trobe SRC Legal Service and WHCLS in a 2-semester course. The offering of placements at 2 legal services was considered to enhance the learning experience of students. The revised Clinical Legal Education course was first offered in 1987 with a quota of 24 students. The course 'sought to link clinical skills, substantive law, research, exposure to case work environments and techniques of public interest legal analysis. ${ }^{32}$

The La Trobe SRC Legal Service maintained an involvement in the clinical program until 1992 and WHCLS remains a major placement site. The distinctive nature of the La Trobe program, as one offered to non-law students, changed in 1991 when the Legal Studies Department became the School of Law and Legal Studies. ${ }^{33}$

During the 1990s, the La Trobe clinical program pioneered the development of links with a legal aid commission rather than a community legal centre. From 1994, La Trobe offered an optional one-semester subject, Legal Practice and Conduct, which included clinical placements at the Preston Office of the then Legal Aid Commission of Victoria (now Victoria Legal Aid). ${ }^{34}$ In 1996 , La Trobe commenced a mentoring program which saw a small number of second year students individually placed with magistrates during one semester. There is clearly a strong commitment at La Trobe to continued development of its clinical program.

Several discussions of Australian clinical programs have ignored La Trobe. The discussion of clinical legal education in the Pearce Committee Report focussed on Monash and UNSW. The 1990 Report of the Queensland Working Party on Clinical Legal Education Discussion Paper reviewed the clinics at Monash and UNSW and 3 Canadian clinics but makes no reference to La Trobe. ${ }^{35}$ Perhaps this can be explained by a view amongst law schools that a clinical program in a Legal Studies Department did not provide useful insights for the establishment of a clinic within a law school. In fact, the La Trobe program offers many useful insights into the potential for clinical experiences to show students how the law and legal system may be used to promote social change.

32 Noone, above, note 27.

33 M. A. Noone 'Australian Community Legal Centres the University Connection' in Cooper, J $\mathcal{E}$ Trubek, L. (eds) 1997, Educating for Justice: Social Values $\mathcal{E}$ Legal Education, Dartmouth, 12.

34 J. Dickson Ef M. A. Noone, 'The Challenge of Teaching Professional Ethics', paper presented at the Australasian Professional Legal Education Council International Conference, Skills Development for Tomorrow's Lawyers: Needs and Strategies, Sydney, September 1996, published in Conference Papers Volume 2, 847, 850.

35 D. Pearce, Australian Law Schools: A Discipline Assessment for the Commonwealth Tertiary Education
Commission, 1987, AGPS. See Volume 1, 115, 122-129 (Perhaps this is explained by the Pearce Committee focus on law schools rather than legal studies departments such as that at La Trobe), Queensland Association of Independent Legal Services, Clinical Legal Education Committee, Report of the Clinical Legal Education Committee, November 1990, Appendix B, 5-6. For a more recent example of the lack of attention paid to the La Trobe clinical program, see I. Styles $\mathcal{B}$ A. Zariski, 'Law Clinics and the Promotion of Public Interest Lawyering' (2001) 19 Law in Context 65,66 where reference is made to the positive experiences of the Monash and UNSW clinics but no reference is made to La Trobe. 


\section{University of New South Wales}

The University of New South Wales (UNSW) established its in-house clinical legal education program in 1981 with the opening of Kingsford Legal Centre. Neil Rees, the founding director of Kingsford Legal Centre, attributes the development of the UNSW clinical program to the desire of the recently established UNSW to challenge the pre-eminence of Sydney University. In the late1970s, Sydney University Law School was considered by UNSW to be fairly weak 'so they saw law as an area where they could overtake Sydney fairly quickly. ${ }^{36}$

Both simulation programs and an externship program, established in mid-1975, preceded the establishment of the in-house clinical program. Neil Rees recalls an incident in 1980 when, having been at the UNSW law school for only a week, 'a student came in and told me "I have relatives in a legal firm in New York so I'm going to do my Clinical Legal Experience placement in New York. Will you approve this?"'. The UNSW Trial Practice subject was 'your classical simulation-style subject, running through a whole range of litigation with students playing all the major roles. ${ }^{37}$

The UNSW clinical program is distinctive in a number of respects. Kingsford Legal Centre developed a very strong test case focus, conducting a series of major anti-discrimination cases. UNSW also used Kingsford Legal Centre to forge novel links between the teaching of law and other disciplines, in this case social work. Kingsford Legal Centre also introduced student supervision practices different to those employed by the Monash program. (These differences are discussed later in this article)

Initially, it had been proposed to operate the UNSW clinical program from Redfern Legal Centre. Redfern Legal Centre was established in $1977^{38}$ and several of the key people in the operation of the centre were academics from the UNSW Law School. In Neil Rees' view, 'the people who ran Redfern were the people from the UNSW Law School. They were the same people just with different hats on. The movers and shakers at Redfern were John Basten, Terry Budden, John Kirkwood, Robyn Lansdowne. 39

A meeting was convened by Rees early in 1980 with key Redfern people (those referred to above plus key staff - Roger West and Clare Petre). 'The Redfern people pretty quickly decided that it would somehow taint the intellectual purity of the Redfern Legal Centre and they were reasonably well funded, didn't want any resources UNSW could offer them and, I think, feared a university takeover of Redfern at the time... These were fairly junior members of staff and they feared the professoriate taking over their baby.' While Redfern Legal Centre did not become part of the clinical program, harmonious relationships were maintained between the law school and the centre.

The planning for the clinical program clearly benefited from Neil Rees' experience at Monash with the development of Springvale Legal Service. The importance of having the clinic coordinator/director as a full-time member of academic staff was recognised. Student supervision and the teaching of the classroom component of the subject comprised this staff member's teaching load. ${ }^{40}$ Rees also noted, 'We should learn from the Monash experience and discourage the use of academic teaching staff who are admitted to practise, but who may lack substantial experience in the necessary areas of law.' ${ }^{41}$

36 Neil Rees, personal interview, 4 September 1997

37 Id

38 See D. Neal (ed) On Tap, Not On Top: Legal Centres in Australia 1972-1982, 1984, Legal Service Bulletin Co-operative.
39 Neil Rees, personal interview, 4 September 1997

40 Neil Rees, Clinical Legal Education (18 March 1981), 15

41 Id 
As late as the end of March 1981, Neil Rees was writing that it would take a considerable period of time to establish the clinic. 'It may be possible, if finance were available, to open the clinic sometime in the second half of 1981. It might be more realistic to aim for a date early in 1982.42 However, the Kingsford Legal Centre was established on 27 July 1981. It was officially opened by Mr Frank Walker, the then Attorney-General of New South Wales on 9 September 1981.'43

The UNSW Law School encountered significant resistance from the Law Society of New South Wales to the establishment of the clinic. Neil Rees attributes this in part to the links between the law school and Redfern Legal Centre. 'Redfern had had lots of run-ins with the Law Society from Day One. The people at Redfern were behind the establishment of the Australian Legal Workers Group which was setting itself up as the alternative law society for radical young lawyers. ALWG was a very volatile organisation... The Law Society saw Redfern, ALWG, Kingsford, Ron Sackville and John Basten and others as this sort of amorphous group of feared lefties. The Aboriginal Legal Service as well. The tentacles were all there. They were pretty horrified as to what was going to happen... So, I found myself at 30 years of age sitting down negotiating with the President and Secretary of the Law Society about the opening of Kingsford and what type of practising certificate they were prepared to give me. ${ }^{44}$

Kingsford Legal Centre quickly developed a substantial litigation practice, especially in the areas of anti-discrimination and domestic violence. Up to 75 anti-discrimination cases were conducted each year and on 6 occasions, these cases were taken to the High Court of Australia. ${ }^{45}$ Domestic violence issues were the key focus for Robyn Lansdowne, the casework lawyer at Kingsford Legal Centre from 1982 to 1986.

While Kingsford's litigation profile was of considerable benefit to the law school, the relationship between the clinic teachers and other academics suffered when the clinicians sought to have time away from the clinic, either for sabbaticals or to teach other subjects in the law school. The catalyst for the departure from Kingsford Legal Centre of Neil Rees and Robyn Lansdowne in 1986 was 'a big blow-up between clinicians and this new school of legal scholars who were great supporters of clinical in theory so long as two things happened. One, it didn't suck away what they thought was a disproportionate share of the funds and two, that they weren't asked to go and work there.'46

In 1987, the schools of law and social work were more successful in developing links. The Law Foundation of New South Wales funded the School of Social Work at UNSW to report on the feasibility of a legal studies course in the social work degree. As a result of that report, the School obtained a development grant from the University to commence, in 1989, a social work placement at Kingsford Legal Centre. The grant was necessary to cover the cost of a social work supervisor at the Centre, and to defray the administrative costs to the Centre of the social work placement. ${ }^{47}$

In 1991, Kingsford Legal Centre Director, Simon Rice reported that the 'presence of an academic/practitioner from the Social Work School, as well as three students on placement, has been of great benefit to the social work studies. More importantly, from the clinical legal education view, it has added a new dimension to the legal casework possibilities and has invited students to

42 Ibid, 7

43 N. Rees 8 R. Lansdowne, Report to the School on Clinical Legal Education, 6 October 1983, 3

44 Rees, personal interview, 4 September 1997

45 J. Giddings, 'Casework, Bloody Casework' (1992) 17
(6) Alternative Law Journal 261, 263

46 Rees, personal interview, 4 September 1997

47 S. Rice, Review of the Clinical Legal Education Program in the Law Faculty at the University of New South Wales (June 1991) 15 
take a close look at the way lawyers may be introduced to working with related professions.' 'It has been a considerable challenge to the supervisors and to the students to explore the possibilities of the two professions working co-operatively. The project requires further time and resources, but shows considerable promise if it can be maintained. 48

\section{Supervision of First Interviews - a key teaching difference}

In a 1984 paper, Robyn Lansdowne \& Neil Rees, the clinic teachers at Kingsford, noted that they faced the 'difficult task of leading students to believe that they must accept responsibility for the conduct of a particular case whilst at the same time ensuring that our clients are not disadvantaged in any way by student involvement. In part, we have to create an illusion of responsibility. ${ }^{49}$ In a 1983 paper, they had referred to their approach to supervision being 'akin to placing students on a rope. The rope is gradually let out if a student is performing well. If a student fails to perform adequately we are forced to draw in the rope and explore every minor detail of a case with the student.' 50

One mechanism used to support this illusion of responsibility remains a key difference between clinical programs in New South Wales and programs in Victoria, Western Australia \& Queensland. While all Australian real-client clinical programs provide students with the opportunity to take instructions from clients without their supervisor being present, different approaches are taken to the provision of advice to the client once the student has discussed the situation with their supervisor. When a client is being interviewed for the first time at either the UNSW or Newcastle clinic, the student will not advise the client alone. They do so with their supervisor. Clinical programs outside New South Wales have adopted the approach pioneered at Monash whereby the student returns to the client and advises them unaccompanied by a supervisor. Students involved in the La Trobe clinical program did not conduct client interviews until the second half of the 1990s, by which time the La Trobe Legal Studies Department had become a Law School.

The Monash approach was based on the importance of the student taking responsibility for the client and to be seen by the client as doing so. Students would first observe interviews conducted by their supervisor early in their placement before being given the opportunity to conduct interviews and provide advice without their supervisor present. Simon Rice viewed the Kingsford approach as appropriate both from a client service perspective and educationally. While not wanting 'to take away the unique student-client dynamic' he saw 'a very useful role for a solicitor to lead by example and teach' as well as to safeguard the quality of advice provided 'when there's that degree of seriousness. ${ }^{51}$

48 S. Rice, 'Some Observations on the Operation of a Clinical program in New South Wales', undated, 12

49 R. Lansdowne $\mathcal{E}$ N. Rees, Kingsford Legal Centre: A Clinical Experience, Paper to the 1984 conference of the
Australian Law Teachers Association, 10.

50 N. Rees $\mathcal{E}$ R. Lansdowne, Above, Note 43, 35.

51 Simon Rice, personal interview, 14 February 1997 


\section{Programs that did not eventuate}

Several other Australian law schools considered the establishment of clinical programs in the late 1970s and 1980s. In 1975, moves to establish a clinical program at the Australian National University (ANU) came to nothing after the Federal Budget, delivered by Labor Treasurer Bill Hayden, failed to deliver additional funding for universities. The then Dean of Law at ANU, Lesley Zines was very supportive of moves to establish the clinic. ${ }^{52}$

The call for a clinical program at the ANU was renewed in 1978. Jack Goldring and Roger Hamilton produced a discussion paper which suggested that without a clinical program, students 'are denied a perspective of the law which, in our view, is essential to a critical awareness of the workings of the legal system. ${ }^{53}$ Again, despite support, the clinic proposal was not adopted due to resource issues.

There were also proposals in the late-1970s to establish a clinical program at Macquarie University, in conjunction with the Macquarie Legal Centre. Ben Boer and Jack Goldring proposed the development of a clinic like that operating at Springvale Legal Service and Goldring considers they were close to receiving support from the Macquarie Vice-Chancellor until funding issues once again intervened. ${ }^{54}$

In 1983, Diana Hardy, a PhD student at the University of Western Australia (UWA) visited the Monash and UNSW clinics and then reported to the UWA Law School regarding the prospect of establishing a clinical program. ${ }^{55}$ There was already a well-established legal service operating at UWA, the Parkways Legal Service. While students at the Parkways Legal Service observed client interviews conducted by lawyers, they were not given responsibility for those clients and their cases. Gosnells Community Centre subsequently approached UWA with a proposal to establish a clinic but it did not eventuate. ${ }^{56}$

\section{The I990s - Renewed Interest in Clinical Legal Education}

The number of law schools in Australia expanded dramatically following a range of reforms to the university sector in $1987 .{ }^{57}$ Interest in clinical legal education was reactivated with a number of the newly established 'third wave' law schools considering the establishment of clinical programs. Not all of these new programs have made use of the live-client model with simulation-based and placement activities also being characterised as clinical. Clinic appears to have been viewed by some of these new schools as a means of differentiating themselves from other new law programs in an increasingly competitive environment. ${ }^{58}$

52 Jack Goldring, personal interview, 9 September 1997

53 J. Goldring 82 R. Hamilton, above, note 6, 1

54 Jack Goldring, personal interview, 9 September 1997

55 D. Hardy, Report on Clinical Legal Education, undated.

56 Michael Hovane, personal interview, 14 May 1999

57 McInnis and Marginson note that from 1987 to 1992, law student numbers rose by $58.7 \%$, making law the third fastest growing discipline during that period. C. McInnis 85 S. Marginson, Australian Law Schools After the 1987 Pearce Report, (1994) AGPS, Canberra, 13.

58 See R. Handley 8 D. Considine, 'Introducing a ClientCentred Focus into the Law School Curriculum' (1996) 7 Legal Education Review 193 at 208 for a discussion of the increasingly competitive law school environment in Australia. 


\section{The Newcastle Professional Program}

The clinic-oriented law degree at the University of Newcastle is the largest and most ambitious of these new programs. The Newcastle program enables students to satisfy their post-degree Practical Legal Training requirements through their undergraduate program by way of involvement in a range of clinical activities. ${ }^{59}$ The University established the Newcastle Legal Centre (since renamed the University of Newcastle Legal Centre) which has been the key clinic site. The Legal Centre has been involved in an impressive range of major litigation, particularly in relation to police accountability. ${ }^{60}$

A substantial amount of limited-term 'soft money' was used to develop the Newcastle Legal Centre as the program's centrepiece. The external funds used to fund the development of the clinical program were provided by the Solicitors Trust Account Fund. ${ }^{61}$ From 1995, Newcastle Law School received a clinical loading of approximately $\$ 250,000$ per year from central university funds. This payment recognised that the Relative Funding Model used by the Commonwealth Department of Education, Training and Youth Affairs renders it almost impossible for law schools to maintain substantial clinical programs. ${ }^{62}$

Other Australian law schools also developed a substantial commitment to clinical teaching in law during the 1990s. After the failure of efforts to develop clinic arrangements which would include all the law schools in South-East Queensland, Griffith University established a clinic relationship with Caxton Legal Centre and now operates 6 clinical programs. ${ }^{63}$ James Cook University also operates a clinical program with Townsville Community Legal Service. Queensland University of Technology places students with Legal Aid Queensland who are supervised by Legal Aid Queensland staff.

\section{Murdoch - Attracting Direct Commonwealth Support}

The establishment in 1997 of the Southern Communities Advocacy Law Education Service (SCALES) by Murdoch University is significant in the development of Australian clinical legal education in several respects. SCALES was the first clinical program to receive direct Commonwealth Government funding and continues to receive such funding as one of the 4 programs supported by the establishment of a CLE funding program as part of the 1998 Federal

59 J. Boersig, 'Clinical Legal Education: The Newcastle Model', paper presented at the Australasian Professional Legal Education Council International Conference, Skills Development for Tomorrow's Lawyers: Needs and Strategies, Sydney, New South Wales, September 1996. Published in Conference Papers, Vol. 1, 463.

60 For example, the Legal Centre has been acting for the family of Leigh Leigh, a Newcastle teenager who was murdered in 1989 and the family of Roni Levi who was shot dead by police on Bondi Beach in July, 1997. See R. Watterson, R. Cavanagh Eु J. Boersig, 'Law School Based Public Interest Advocacy' (2002) 2 International Journal of Clinical Legal Education 7.

61 This fund comprises interest payments on funds held in solicitors' trust accounts which are not centrally deposited. The fund was established in the 1980's following agreement between the major banks and the Law Society of NSW.

62 The implications of the DETYA Relative Funding Model for clinics are discussed in J. Giddings, 'A Circle Game: Issues in Australian Clinical Legal Education' (1999) 10 (1) Legal Education Review 33, 44-46.

63 Griffith operates a generalist and a specialist family law clinic in partnership with Caxton Legal Centre, a specialist alternative dispute resolution clinic in partnership with the Alternative Dispute Resolution Branch of the Queensland Department of Justice and Attorney-General, an externship program, a public interest lawyering program with the Queensland Public Interest Law Clearing House and an Innocence Project. 
budget. Murdoch remains the only Australian Law School which attracted substantial financial support from outside the university for the establishment of a clinical program.

The success of Murdoch in obtaining direct funding from the Commonwealth government for the establishment of their clinic has clearly had a significant effect on the development of clinical legal education in Australia. To some extent, the SCALES story is one of 'being in the right place at the right time' but it is more an example of developing a persuasive case for support. Murdoch Law School, with support from the central University, worked methodically to gather information about CLE practice and then worked with interested parties to address a wide range of issues. Ultimately, Murdoch has been able to develop a range of funders for SCALES. Murdoch University's agenda in promoting the SCALES concept went beyond the Law School. The University was directly focussed on the development of its new campus at Rockingham in the rapidly developing region south of Perth and to institutionalising its provision of community service to that region.

SCALES is the first Australian CLE program involving a formal mentoring process with another existing clinical program, in this case involving clinicians from Monash. Most other Australian clinics were established with the direct involvement of people who had experience working in similar programs elsewhere. Murdoch relied on Chris Shanahan, a jurisprudence lecturer with experience working in community legal centres in New South Wales, to develop a clinic proposal and pursue funding avenues. Shanahan's community legal centre background was arguably very important to the success of Murdoch in developing a viable model for the proposed clinic and to ensuring the strong community service focus the clinic would adopt. The close connections between the Australian clinical legal education and community legal centre movements are well illustrated by the Murdoch example.

\section{Clinic as a Marker of Difference}

Clinics continue to be used to differentiate some law schools from others. The increase in the number of Australian law schools during the 1990s appears to have intensified both the need for new law schools to 'find a niche' and the attractiveness of clinics as a possible marker of difference. Just as Kingsford Legal Centre was part of the UNSW Law School challenge to Sydney Law School in the early 1980s, SCALES differentiated Murdoch Law School from other law schools west of the Nullarbor in the mid-1990s.

Archie Zariski notes that Murdoch was a new law school at the time of developing the CLE proposal and that 'everyone at Murdoch was looking for ways to distinguish Murdoch, to take an innovative approach to legal education, to do things a little bit differently to the traditional. . . We were all looking for ways to make Murdoch stand out as a new law school and I thought that a clinical approach might well be one of them. ${ }^{64}$

Griffith Law School operates a much more substantial clinical program than the other South East Queensland law schools, Bond University, Queensland University of Technology and University of Queensland. Griffith Law School offers 6 different clinical courses which feature heavily in promotional literature from both the law school and the university. In particular, the prospect of students having opportunities to take responsibility for legal issues faced by real people has been emphasised.

64 Archie Zariski, personal interview, 14 May 1999 


\section{Growing Commonwealth support for clinics}

Following the pilot phase of the SCALES project, the Commonwealth government made a more substantial commitment to promoting Clinical legal education. In February 1999, the Commonwealth Attorney-General, Daryl Williams selected 4 clinical legal education projects to be funded under its Clinical Legal Education Funding Program. Funds have been provided to Griffith University, Monash University, Murdoch University and the University of New South Wales (UNSW). Both Griffith and Monash established specialist family law clinical programs, UNSW established an employment law service and Murdoch used their funding to maintain existing operations. As might be expected, all 4 programs supported by the commonwealth strongly emphasise the importance of community service objectives.

The Commonwealth's interest in clinical legal education has been prompted both by a concern to deliver cheaper legal services to the community as well as an interest in improving legal education. The question is the extent to which both community service and educational objectives can be achieved in the same program. ${ }^{65}$ To date, the Commonwealth have been supportive of the approaches taken by each of the funded programs with funding continuing beyond the initial 3-year allocation.

\section{Student Appearance Work}

The rise in the number of unrepresented litigants appearing before courts may provide the catalyst for Australian clinical programs to follow the United States of America in providing greater opportunities for students to engage in real advocacy work. Advocacy training in Australian law schools has to date been dominated by simulation exercises. ${ }^{66}$ Australian Law Schools including Newcastle, Monash and Griffith incorporate student appearance work into their clinical programs. ${ }^{67}$ These programs rely on the discretion of individual magistrates and judges to grant leave to students to appear in their court and this reliance created difficulties for the Monash program in $1997 .{ }^{68}$

Student appearance rights has been an issue of longstanding interest for clinicians with a wide range of proposals, involving courts (including the Family Court and Magistrates Court), tribunals and bodies like the Tribunal for the New South Wales Australian Football League. In October 1987, the League wrote to UNSW Law Dean Garth Nettheim 'to ascertain if we might interest some students who could be looking to gain practical advocacy experience in a court room type situation in assuming an advocate's role'. ${ }^{69}$

65 J. Giddings, 'The Commonwealth Discovers Clinical Legal Education' (1998) 23 (3) Alternative Law Journal 140

66 A. Lynch, 'Why Do We Moot?: Exploring the Role of Mooting in Legal Education' (1996) 7 Legal Education Review 67, M. Keyes 8f M. Whincop, 'The Moot Reconceived: Some Theory and Evidence on Legal Skills' (1997) 8 (1) Legal Education Review 1.

67 For an outline of the Monash program, see S. Campbell 'My Learning Friend' (1993) 67 (10) Law Institute Journal 915
68 Changes to the Legal Profession Practice Act have raised concerns regarding the standing of students to appear in court as advocates. See J. Faine, 'Student Counsel Scheme Under Threat' (1997) 71 (1) Law Institute Journal 17. Noone suggested in 1991 that legislative amendment as the best way to create the certainty needed to promote student appearances. Noone, M.A., 'Student Practice Rule - Is it Time?' (1992) 66 (3) Law Institute Journal, 190.

69 Letter to Garth Nettheim from Ian Garland, Chief Executive, NSW Australian Football League, 30 October 1987. 
As part of the 1990 review of the operations of Kingsford Legal Centre, a survey was conducted of students who had completed the Clinical Legal Experience subject between 1986 and $1990 .{ }^{70}$ Seventy percent of respondents identified their reason for choosing to do the clinic subject as being 'to develop practical legal skills and experience' while $23 \%$ referred to 'wanting to work in a community legal centre'. ${ }^{71}$ The most common suggested improvement to the subject was the incorporation of more court experience and advocacy work. ${ }^{72}$

In 1998, Judith Dickson published a comprehensive article arguing in support of clinical legal education students being given a statutory right of audience before Australian courts. ${ }^{73}$ Dickson outlined the close student supervision processes used by Australian clinics. She then argued that Australian clinical programs 'emphasise the assumption of responsibility by the students for the satisfactory conduct of clients' files. ${ }^{\text {'74 }}$ This assumption of responsibility involves students learning and practising the application of legal rules and processes as well as ethical practices. This need to adhere to the standards of competency and ethical conduct of lawyers is argued to distinguish clinical legal education students from other non-legally qualified persons.

\section{Specialist Clinical Programs}

There has also been a move towards establishing clinical programs in specialist areas of law. Various law school have established specialist clinical programs, both in-house and in conjunction with a wide range of external organizations, from private legal firms to public interest law offices. ${ }^{75}$ Monash operates 2 specialist CLE programs; one in family law and another in which a small group of experienced students provide legal advice to victims of sexual assault. ${ }^{76}$

Griffith operates 2 specialist CLE programs, an Alternative Dispute Resolution clinic with students being placed with the ADR Branch of the Queensland Department of Justice ${ }^{77}$ and a family law clinic focussing on people in regional Queensland and on unrepresented litigants. Both the Griffith and Monash family law clinics have been funded by the Commonwealth AttorneyGeneral's Department. UNSW operates a specialist employment law service, also with financial support from the Commonwealth.

It is likely that further specialist clinical programs will be developed, in schools seeking to make broader use of a strength in a particular substantive legal area or to meet community service obligations to groups with particular legal service needs. There is clearly scope for advanced elective courses to incorporate a clinical component. Areas likely to see specialist clinics develop include refugee law, intellectual property and mediation.

70 MSJ Keys Young, Clinical Legal Experience: Survey of Former Students, January 1991

71 Ibid, 5

72 Ibid, 15

73 J. Dickson, 'Students in Court: Competent and Ethical Advocates' (1998) 16(2) Journal of Professional Legal Education 155.

74 Ibid, 168.
75 See Kingsford Legal Centre, Clinical Legal Education Guide 2001/2002,

76 A. Evans, 'Specialised Clinical Legal Education Begins in Australia' (1996) 21 Alternative Law Journal 79.

77 J. Giddings, 'Using Clinical Methods to Teach Alternative Dispute Resolution: Developments at Griffith University' (1999) 10 (3) Australasian Dispute Resolution Journal 206 


\section{Links with Practical Legal Training}

There has recently been substantial 'movement at the station' in relation to the provision of Practical Legal Training (PLT) programs by Australian law schools. ${ }^{78}$ The expansion in New South Wales of the number of PLT providers has been followed by similar moves in both Victoria and Queensland. In states where articles of clerkship are still available as the alternative post-degree route to admission, there have been moves from major national law firms to have their 'graduate clerks' complete a PLT program rather than articles. ${ }^{79}$

The dividing line between undergraduate CLE and PLT courses is becoming increasingly difficult to define. This lack of clarity arises from changing perceptions of the place of legal skills teaching in undergraduate law programs. Rice states that 'In those jurisdictions such as Australia where articles or post-degree, pre-admission practical education courses are compulsory, the need for undergraduate skills training is less pressing. Consequently the teaching of legal skills [at undergraduate level] need be necessary only to a degree that enables students to work effectively in the clinical program while pursuing other aims. ${ }^{80}$ This view of the limited role of skills training in CLE programs is likely to be undermined due to extra pressure being placed on the PLT system with the increase in law graduates seeking entry to the profession. As Sue Campbell anticipated in 1995, PLT providers are now granting some students credit for skills learning contained in their LLB studies, including involvement in a CLE program. ${ }^{81}$

Clinic teachers involved in the development of PLT programs need to encourage a broad perspective to be taken of pre-admission training for lawyers, moving away from a transactional focus. Newcastle Legal Centre founder, John Boersig has noted that planners must keep in mind the need to ensure courses do more than simply teach students how to fill in forms. Such programs need to emphasise the teaching of generic skills 'essential to a broad range of legal activities'. ${ }^{82}$

\section{Greater Expectations}

Law schools are now expecting more and more from their clinical programs and clinicians. Clinics are promoted to students as the best environment in which to develop 'hands on' legal skills while being showcased to the general community as examples of university commitment to community service and access to justice. Interestingly, we have seen name changes for several Australian clinics, changes clearly designed to more closely connect these clinics with their law school and university. Springvale Legal Service has become the Springvale Monash Legal Service and the Newcastle Legal Centre has become the University of Newcastle Legal Centre.

Clinical programs, combining small class sizes with community service, have been used by universities to showcase excellence in teaching. Clinicians have been well represented in university teaching awards. In the first 5 years of the Australian Awards for University Teaching (1997-2001), clinical teachers from Griffith (1999), Monash (1998) and UNSW (2001) have been finalists for the Australian Award for University Teaching in Law and Legal Studies with the Griffith and UNSW

78 A. Lamb, 'Preparation for Practice: Recent Developments in Practical Legal Training in Australia' Paper Presented at the Commonwealth Legal Education Association Conference 2000, Adelaide, April 2000.

79 C. Banham, 'Big Firms Take Student Training InHouse' Friday, May 5, 2000 Justinian.
80 Rice, above note 40,25

81 S. Campbell, Clinical Legal Education Newsletter, No.8, November 1995, 2

82 J. Boersig, Above, note, 466

83 J. Giddings, Above, Note 62, 38. 
teachers having the good fortune to receive the award. The work of SCALES was a key feature of Murdoch University's successful nomination for the 1998 Australian Award for University Teaching for services to students and the Rockingham region.

\section{Themes in Australian Clinical Legal Education}

There are some underlying similarities that should be considered in attempting to identify the character of Australian CLE. They relate to:

- Emphasising community service, including focussing on real cases rather than simulations;

- Enhancing Student Learning - 'Legal Education in Context';

- Practical legal scholarship;

- Client-centred lawyering.

\section{Emphasising Community Service}

In my view, Australian clinical programs have been shaped to a significant extent by the backgrounds of the people working in those clinics. Australian clinical programs tend to have been and continue to be staffed by people with a strong community legal centre / legal aid background. This tends to bring with it a strong commitment to community service and to using the law and legal system to achieve community development objectives. ${ }^{83}$

Australian clinical programs are now increasingly focussed on taking their work beyond the traditional service delivery model of advice and representation for individual clients. This is being done principally to enhance the impact of the community service provided and also to enrich student learning. Various models have been developed to enhance and extend the impact of the work of clinic students and teachers.

Clinical programs in New South Wales have a particularly impressive record of running major superior court public interest cases. There are the continuing efforts of teachers and students involved at the University of Newcastle Legal Centre in cases such as the Eastman ${ }^{84}$ appeal to the High Court, the compensation claim arising from the 1993 murder of Leigh Leigh and litigation arising from the police shooting of Roni Levi. ${ }^{85}$ The Newcastle program has been particularly effective in pursuing issues regarding police accountability using a range of mechanisms, including strategic work with the media, submissions to government and acting at coronial and other inquiries. Another recent example is that of the Stolen Generations testcases conducted by Kingsford Legal Centre. ${ }^{86}$

Other clinics have adopted community development models with a view to involving their clients and others in addressing issues of community concern. Such models utilise non-casework approaches and yet are obviously informed by the casework conducted by the clinical program and the agency housing the clinic. Examples of such approaches are those developed at Monash and Griffith. Adrian Evans refers to the process of community development identified in the 1970s by

84 Eastmanv The Queen [2000] HCA 29 (25 May 2000)

85 R. Watterson, R. Cavanagh \&ु J. Boersig, Above, Note 60, 7-37
86 Williams $v$ The Minister Aboriginal Land Rights Act 1983 and The State of New South Wales [2000] NSWCA 255 
the Brazilian educator, Paulo Friere and the need for clinicians to help students and clients to move beyond individual reflection to group reflection upon the underlying social injustices which diminish an equitable society. ${ }^{87}$

The Griffith clinical program includes students working in groups on community development projects. Given the complex and ongoing nature of many community concerns, discrete projects are designed in relation to particular issues which can be completed by successive groups of students, each building on the work done by previous groups with continuity being provided by clinic and community legal centre staff acting as project supervisors. Project areas have included property rights of mobile home park residents and litigation funding arrangements (particularly 'no win, no fee').

\section{Legal Education in Context}

The emphasis placed by Australian clinic teachers on student learning has significantly increased in the past decade. In a series of interviews, many clinicians involved in early Australian programs told me that they had started their time as student supervisors without having considered the teaching side of the process in great detail. They tended to be more concerned with community service and law reform issues. Discussions with current clinic teachers reveal a more substantial understanding of the scope for improving service and law reform achievements through more effective teaching practices. There is also a greater awareness of the potential for clinic-based learning to complement the other learning in which law students are involved.

The work done by Simon Rice in his time at Kingsford Legal Centre from 1989 to 1995 represents the most substantial example of Australian clinical legal education scholarship produced to date. Rice was greatly assisted in this work by the UNSW Law School decision to allow the clinic to not take on students in Semester 2, 1990. In the absence of students, Kingsford Legal Centre conducted a comprehensive review of its operations. The UNSW Law School received support from the Law Foundation of NSW for Rice to visit clinical programs in the USA, England and Canada.

Rice's contribution has had a significant impact on the development of clinics in Australia during the 1990s. A Guide to Implementing Clinical Teaching Method in the Law School Curriculum ${ }^{88}$ was published in 1995 and provided a useful account of the issues facing people considering the establishment or refinement of a clinical program. The clinical programs established in the 1990s also benefited from the increased interest in legal education in Australia exemplified by the Australasian Law Teachers Association Law Teaching Workshop and the book The Quiet [R]evolution: Improving Student Learning in Law by Le Brun and Johnstone. ${ }^{89}$

The ethics focus of Australian clinical legal education has been more clearly articulated in recent years. The La Trobe initiative to develop a clinic-based offering of the ethics subject required for admission to legal practice is a significant development in several respects. As well as being the first Australian clinical program to involve students taking responsibility for clients within a legal aid office rather than a community legal centre, the ethics orientation of the subject lends itself to more extensive discussion of professional responsibility issues.

87 A. Evans, 'Client Group Activism and Student Moral Development in Clinical Legal Education' (1999) 10 Legal Education Review 179.

88 S. Rice $\mathbb{E}$ G. Coss, A Guide to Implementing Clinical Teaching Method in the Law School Curriculum,
January 1996, Centre for Legal Education

89 M Le Brun $\mathcal{B} R$ Johnstone, The Quiet Revolution: Improving Student Learning in Law, Law Book Company, 1994 
Judith Dickson and Mary Anne Noone rightly identify that the clinical setting 'constantly gives rise to spontaneous and various ethical questions which challenge and test students'. ${ }^{90}$ Given that written ethical conduct rules are 'signposts at the crossroads not a fence along the entire length of the highway' ${ }^{\prime 1}$, clinics provide students with opportunities to develop the ability to identify and address ethical issues in relation to matters including conflict of interest, confidentiality and legal professional privilege.

The Murdoch clinical program (SCALES) has identified the importance of involving students in providing legal assistance to asylum seekers. In 2000, Mary Anne Kenny and Anna Copeland persuasively argued that such cases are effective in 'encouraging students to recognise systemic injustice'. ${ }^{92}$ These cases 'have a profound effect on the students as they are faced with the broader social and political issues that these cases present. ${ }^{93}$ The intensification of the Australian public debate on asylum seeker issues in 2001 and 2002 reinforces their argument. Kenny and Copeland state that what they "hope to achieve as clinical supervisors is to foster a "rights based" methodology that students will apply across all their legal work. This involves students gaining an understanding of, and a commitment to, fundamental human rights as an important principle of any legal practice. ${ }^{\prime 94}$

At Monash, Adrian Evans is now engaged in work seeking to more clearly articulate the links between community development processes and the development of values in law students. Evans has recently written of the need for clinical supervisors to stimulate respectful argument amongst their students in relation to competing moral viewpoints identified through the process of community development. ${ }^{95} \mathrm{He}$ is also involved in a project designed to determine the values which appear to characterise the mass of Australian lawyers in their early careers.

\section{Practical Legal Scholarship}

During 1984, the Director of Research in the Monash Law Faculty, Professor Richard Fox, wrote to the Dean articulating a concern often expressed by clinical teachers:

'It is apparent that academic staff who devote their time whole-heartedly to the clinical programme may later find themselves at a disadvantage in securing promotion because of their reduced productivity during their time in the programme. Their contribution to the teaching, community service and administrative sides of the legal service are not seen by those who place prime value on research as compensating for an apparent weakness in their publication record... The acceptance of the clinical programme and the work of its staff as part of mainstream academic life will be enhanced if it has a built-in research element. ${ }^{96}$

90 J. Dickson 8 M. A. Noone, 'The Challenge of Teaching Professional Ethics', paper presented at the Australasian Professional Legal Education Council International Conference, Skills Development for Tomorrow's Lawyers: Needs and Strategies, Sydney, September 1996, published in Conference Papers Volume 2, 847.

91 F. Oatway, 'Motivation and Responsibility in Tax Practice: The Need for Definition' cited by Y. Ross, Ethics in Law: Lawyers Professional Responsibility and Accountability in Australia, 3rd.ed. , 2001, 45
92 M. A. Kenny \&ु A. Copeland, 'Clinical Legal Education and Refugee Cases: Teaching Law Students About Human Rights' (2000) 25 (5) Alternative Law Journal 252

93 Ibid, 253

94 Ibid.

95 Evans, above, note, 181.

96 Memorandum to Professor R. Baxt from Professor R. Fox re. Research and the Clinical Legal Education Programme dated 30 July 1984. 
While Australian clinical teachers have struggled for acceptance as mainstream academics, many have made substantial contributions to developing a body of practice-related legal scholarship. Perhaps the best example of such scholarship is the Lawyers Practice Manual, published in New South Wales in 1983, Victoria in 1985 and Queensland in 1993. Clinicians made very substantial contributions to the development of the New South Wales and Victorian manuals in particular. The Lawyers Practice Manual (New South Wales) was developed with a very substantial contribution from Neil Rees, then responsible for the UNSW clinical program. The 4 founding editors of the Lawyers Practice Manual (Victoria) were all clinic teachers from Monash ${ }^{97}$ and Springvale Legal Service is listed as the author on the spine of the manual.

The need for such a manual was 'first discussed at a seminar arranged for legal aid lawyers by the Australian Legal Workers Group' which identified 'a glaring gap in legal literature and training: too much hard practical knowledge inaccessibly stored in the heads of those who have gained it by long experience. 98

Clinical teachers have been and continue to be substantial contributors to the Alternative Law Journal, which from 1974 until 1991 was known as the Legal Service Bulletin. There have also been major reports written by clinical teachers on matters related to their casework, often in conjunction with other community legal centre staff. The Urgent Repairs Needed report, published by the Federation of Community Legal Centres in 1988, highlighted the urgent need for reform of the law concerning motor vehicle property damage. ${ }^{99}$ Springvale Legal Service Co-ordinator, Simon Smith was a driving force behind this important publication. Clinicians have also been prominent in policy formulation in relation to justice issues with Mary Anne Noone serving as a member of the National Legal Aid Advisory Committee and as a director of Victoria Legal Aid. Simon Rice served a term as a legal aid commissioner in New South Wales while the author served 2 terms as a legal aid commissioner in Victoria.

Academics from the University of Newcastle Legal Centre have published a series of reports as part of the public interest litigation in which they have engaged. ${ }^{100}$ Such reports 'have sought redress of individual injustice, exposed failures in legal fact gathering and analysis and laid ground for more general reforms.' ${ }^{101}$ In my view, such reports represent an important form of practical legal scholarship which should be developed further by academics involved in other Australian clinical programs.

Clinics are now increasingly being seen as potential legal research sites, providing opportunities for clinicians to obtain prestigious research grants. With student supervision loads lighter than they were for Australian clinicians in the 1970s and 1980s, research opportunities are more likely to be pursued. Monash clinician, Adrian Evans is the Second Chief Investigator for a research project on the development of values in new lawyers which received Australian Research Council funding

97 Simon Smith, Maureen Tehan, Sue Campbell \&ु Guy Powles

98 N. Rees, C. Ronalds Ë R. West, 'Preface', Lawyers Practice Manual (New South Wales), Law Book Company, Sydney, October 1993.

99 S. Bailey, S. Liden Eु S. Smith, Urgent Repairs Needed: Motor Vehicle Property Damage in Victoria, (October 1988). For commentary, see J. Giddings, 'Casework, Bloody Casework' (1992) 17 (6) Alternative Law
Journal 261, 263-264

100 For example, see R. Cavanagh, J. Boersig $\mathcal{E} R$. Watterson, The Murder of Leigh Leigh November 1989 - A Forensic Report (1996), R. Cavanagh $\mathcal{E}$ R. Pitty, Too Much Wrong - Report on the Death of Edward James Murray (1997) and R. Watterson et al, A Very Public Death: The Police Shooting of Roni Levi.

101 R. Watterson, R. Cavanagh \&J J. Boersig, Above, Note 60, 19 
for 2001-2003. It will obviously be a challenge for clinicians to balance their involvement in a timeconsuming but highly rewarding teaching process with engagement in research and other scholarship.

\section{Client-centred Lawyering}

Australian clinical programs have strongly emphasised the importance of students using multidisciplinary approaches to address the issues facing their clients. Both Springvale Legal Service and West Heidelberg Community Legal Service shared premises right from their inception with major community-based service providers. ${ }^{102}$ UNSW pioneered the offering of a combined degree in law and social work incorporating a substantial placement component at Kingsford Legal Centre.

The work of both clinicians and students has been enhanced by this relatively easy access to other professionals. In 1984, Simon Smith wrote that 'Work in the centre provides students in most cases with their first real introduction to the operation and the impact of the legal system. The lasting impression on these future lawyers of this introduction cannot be overestimated.'103 The commitment to multi-disciplinary approaches continues with, for example, the University Newcastle Legal Centre co-locating with other services ${ }^{104}$ and the Griffith clinical program working closely with social workers employed at Caxton Legal Centre. The specialist clinical program established by Monash to assist victims of sexual assault involves participating students in close work with a range of professionals. ${ }^{105}$

Clinical programs have also focussed strongly on developing the client interviewing and advising skills of students. When Adrian Evans devised a clinical course at La Trobe in 1976, it was run with the La Trobe Counselling Service and was designed to introduce client-centred interviewing to the SRC Legal Service. ${ }^{106}$ Extensive use was made of Legal Interviewing and Counselling: A ClientCentered Approach, the pioneering book on by UCLA academics, David Binder and Susan Price. ${ }^{107}$ The earliest seminar programs attached to the Monash and UNSW clinical programs emphasised the development of interviewing skills.

\section{Visions of Professionalism}

In an article in the inaugural issue of the International Journal of Clinical Legal Education, Judith Dickson raises the need for clinic teachers to reconsider the legal professional model which underpins the community service focus of their work. Dickson expresses concern that the organized legal profession makes use of notions of community service in a negative way, 'as a justification for privilege'. ${ }^{108}$ The concern here is that acceptance of this traditional vision of the lawyer as a professional 'is tied to other aspects of the profession which entrench privilege and

102 Springuale Community Aid and Advice Bureau and West Heidelberg Community Health Centre.

103 S. Smith, Above, Note 4, 52

104 Many Rivers Aboriginal Legal Service and the Hunter Regional Office of the New South Wales Legal Aid Commission

105 A. Evans, "Specialised Clinical Legal Education Begins in Australia" (1996) 21 Alt LJ 79
106 Adrian Evans, interview, 17 October 1997

107 D. Binder $\mathcal{E}$ S. Price, Legal Interviewing and Counselling: A Client-Centered Approach, (1977) West Publishing, St Paul.

108 J. Dickson, 'Clinical Legal Education in the 21st Century: Still Educating for Service?' (2000) 1 International Journal of Clinical Legal Education 33, 36. 
injustice - such as monopoly over delivery of services, self-regulation etc.' ${ }^{109}$ Dickson further suggests that clinical legal educators must 'articulate a new vision of the role and function of lawyers in society. This new vision should expressly challenge a notion of "professionalism" that appears self-serving and self-interested.'110

I would challenge Dickson's characterisation of clinicians as relying on a vision of professionalism which contains characteristics which entrench privilege and injustice. It is the abuse of those characteristics which entrenches privilege and injustice. Australian clinicians have long emphasised to their students those aspects of the legal professional ideal which focus on the importance of the work of lawyers to the effective operation of democratic institutions. Lawyers who are independent of government and able to act impartially have an important contribution to make to safeguarding the fairness of administrative processes and the accountability of powerful interests. Many Australian clinical teachers have actively used their work to undermine abuses of professional ideals and have called for change in a range of respects to existing regulatory frameworks. Foremost in this regard has been the work done in the Monash clinical program by Simon Smith and then Adrian Evans. Smith worked with students to highlight inadequacies in the regulatory work of the Law Institute of Victoria, particularly in the practices of certain local lawyers. In Smith's view, it was the series of cases run by Springvale Legal Service against a lawyer named Peter C. Neil that exposed important inadequacies in the disciplinary functions and operations of the Law Institute of Victoria and which gave rise to legislative reforms in the early 1990s. ${ }^{111}$

Smith's work was continued by Evans who also raised important concerns regarding sources of funding used by the Law Institute of Victoria for their disciplinary functions. ${ }^{112}$ Working on these cases persuaded Evans that there was another dimension to developing socially responsible lawyers and that was dealing with lawyers who were unethical. 'You can't just operate at the level of education of good lawyers. You also have to be prepared at some level as a community to deal with lawyers who are rogues.' Evans said 'We couldn't be coherent as a clinical programme unless we were addressing both ends of the problem.' ${ }^{\text {113 }}$

Dickson refers to various official committees convened in Australia during the 1990s which addressed issues related to the regulation of the legal profession. ${ }^{114}$ Community legal centres made substantial submissions to many of these committees. In a number of instances, the community legal centre submissions were heavily influenced by clinicians. For example, the Federation of Community Legal Centres in Victoria made a series of submissions to the Costs of Justice Inquiry and then to the Access to Justice Advisory Committee which were strongly influenced by clinicians

$109 \mathrm{Ibid}, 40$.

$110 \mathrm{Ibid}, 43$.

111 Simon Smith, personal interview, 14 September 2002

112 See A. Evans, 'Professional Ethics North and South: Interest on Clients' Trust Funds and Lawyer Fraud. An Opportunity to Redeem Professionalism' (1996) 3 (3) International Journal of the Legal Profession 281

113 Evans interview, above, note

114 Dickson, above, note 92, 34. These included the Costs of
Justice Inquiry conducted in the early 1990s by the Senate Standing Committee on Legal and Constitutional Affairs, the Law Reform Commission of Victoria reference on Access to the Law in 1992, the Access to Justice Advisory Committee which reported to the Commonwealth Attorney-General in 1994, the Working Party on the Legal Profession which reported to the Victorian Attorney-General in 1995 and the Trade Practices Commission 1994 review of the legal profession. 
including Mary Anne Noone (La Trobe), Adrian Evans (Monash) and myself (La Trobe). ${ }^{115}$ Similar contributions were made by clinicians to the Trade Practices Commission Inquiry into the Legal Profession in 1993 and the Access to Justice Advisory Committee in 1994.

A common theme of such submissions has been that if lawyers do not effectively regulate themselves and if they abuse their professional status, there is a need for reform. I contend that the notion of professionalism articulated in such submissions was not a chimerical ideal but rather one that identified the importance of lawyers in the work of our democratic institutions, in ensuring procedural fairness and monitoring the actions of governments in an era of privatisation as well as the need for lawyers to remain independent of governments, clients and employers. Such submissions can be characterised as recognising the value of the work of lawyers as well as the importance of effective accountability for legal professionals.

\section{Conclusion}

Various factors are contributing to increasing interest in clinical legal education in Australia. Many students are drawn to clinics by a range of factors including the opportunity to be part of much needed community services, to find a practical context for their other law studies and to develop legal practice skills. Law schools and universities have viewed clinics as valuable student learning environments as well as sites for significant community service contributions. Law schools have also used clinics to distinguish themselves from neighbouring law schools in terms of the learning opportunities provided to students. Community legal centres are increasingly interested in potential benefits from links with clinical programs, such as harnessing the enthusiasm and research skills of students as well as developing their base of student volunteers. Further, governments are increasingly interested in the contributions clinics can make to the delivery of legal services.

Australian legal clinicians have worked collaboratively and collectively within their clinics, their law schools and across universities. Many students have been enthused by an enhanced appreciation of the importance of the law to our democracy. Students are able to gain a sense that their efforts can assist people to assert their rights. Many members of the community have received valuable legal assistance. Practices of the legal and other professions, government institutions, the media and the corporate sector have all been subjected to close scrutiny and challenge.

It remains important that clinicians emphasise the need to take a broad approach to their work, an approach that goes well beyond a focus on legal skills development and concentrates on social justice issues. Australian clinicians have taken the broad view in the past and appear likely to continue to do so.

115 See Federation of Community Legal Centres (Vic) Inc, Submission to the National Legal Aid Advisory Committee Review of Legal Aid, July 1989, \&8
Submission to the Senate Inquiry into Costs of Justice, Part 2 The Court System, December 1989 Eु in particular Part 3 The Legal Profession, June 1990. 